\title{
Antalya ilinde tüketicilerin kefir tüketimi ve tüketici davranışları
}

\author{
Consumption of kefir and consumer behaviour in Antalya province
}

\author{
Simge YELCE ${ }^{1} \mathscr{\infty}$, Mevlüt GÜL ${ }^{1}$ \\ ${ }^{1}$ Universtiy of Isparta Applied Sciences, Faculty of Agriculture, Department of Agricultural Economics, Isparta, Turkey.
}

\author{
MAKALE BILGISI / ARTICLE INFO
}

Makale tarihçesi / Article history:

DOI: $10.37908 / \mathrm{mkutbd} .656795$

Geliş tarihi /Received:08.12.2019

Kabul tarihi/Accepted:28.05.2020

\section{Keywords:}

Kefir, Consumption, Logistic, Consumer, Probiotics, Antalya

\footnotetext{
Corresponding author: Simge YELCE

$\triangle$ : simgeyelce@gmail.com
}

ÖZET/ A B STRACT

Atıf / Citation: Yelce S, Gül M (2020) Antalya ilinde tüketicilerin kefir tüketimi ve tüketici davranışları. MKU. Tar. Bil. Derg. 25(3) : 316-325. DOI: $10.37908 /$ mkutbd.656795

\section{Giriş}

Son yıllarda tüketicilerin sağlıklı beslenme bilincinin gelişmesi sonucunda insanlar gıdalardan daha fazla beklenti içine girmiştir. Bu sebeple fonksiyonel gıdalar sanayinin hızla gelişen sektörlerinden biri olma yolunda ilerlemiştir (Oraman ve Yılmaz, 2006). Türk Gıda Kodeksi Fermente Süt Ürünleri Tebliği'nde kefir " fermentasyonda spesifik olarak Lactobacillus kefiri, Leuconostoc, Lactococcus ve Acetobacter cinslerinin değişik suşları ile laktozu fermente eden ve etmeyen mayaları içeren starter kültürler ya da kefir tanelerinin kullanıldığı fermente süt ürünü" olarak tanımlanmaktadır (Anonim, 2009). Kefir bir Orta Doğu içeceğidir. Kefirin isminin Türkçede hoşa giden "keyf" kelimesinden geldiği ileri sürülmektedir. Kefirin kökeni Kafkas Dağları ve Orta Asya olup binlerce yıldır tüketilmektedir (Otles ve Çağındı, 2003).

Geleneksel olarak kefir, kefir danelerinin süt içerisinde fermentasyona uğraması sonucunda oluşan bir süt 
ürünü olup, kefir daneleri kefir üretimi yapıldığı sürece çoğalıp yeni kefir daneleri oluşturabilmektedir (Tomar vd., 2017). Kefir daneleri karnabahar çiçeklerine benzemekte olup, 1-3 cm boyunda, düzensiz şekle sahip sarı-beyaz renkli, sert bir dokuya sahiptirler (Farnworth, 2006).

Kefir 21. yüzyılın yoğurdu olarak bilinmektedir. Kefir, sütün içindeki bütün besin maddelerini içeriyor olması ve kefirin yapısında bulunan mikroorganizmaların etkisi sonucu besin değerinin artması ve vücut tarafından iyi emilebilmesi açısından önem arz etmektedir. Ayrıca kefirin sindirim problemi olanlara çare olabileceği söylenmektedir. Kolay sindirilebilen bir gıda olduğundan hemen her yaşta ve cinsiyette insanlar için uygun olduğu görülmektedir (Karatepe ve Yalçın, 2014).

Kefirin insan sağlığına etkileri arasında; antikansorejenik etki, antialerjik etki, bağışıklık sistemi üzerine etkileri, laktoz intöleransını azaltıcı etki, kolesterol düşürücü etki, sindirim sistemi üzerine etki ve kan şekeri düzenleyici etki yer almaktadır.

Kefir üretimi; geleneksel kefir üretimi ve endüstriyel kefir üretimi olarak iki şekilde yapılmaktadır. Geleneksel kefir tüketiminde evde kefir yapımında süt 5 dakika kaynatılarak bir kaba konulur. Kaba konulan süt $25^{\circ} \mathrm{C}^{\prime}$ ye kadar soğutulduktan sonra sütün üzerindeki kaymak tabakası alınır ve sütün $1 / 3$ 'ü kadar kefir danesi süt içerisine koyularak karıştırılır, kapağı kapatılır, süt oda sıcaklığında inkübasyona bırakılır. Kabın içindeki süt 1824 saat sonunda pıhtılaşır. Pıhtılaşan süt tel süzgeçten geçirilerek daneler ayrılır. Ayrılan daneler kaynatılıp soğutulan su ile yıkanarak bir sonraki kullanım için buzdolabında bekletilir. Süzgeçten geçen pıhtı buzdolabına alınır, 2-3 gün dolapta kaldıktan sonra tüketilebilir (Üstün ve Gökçe,2013). Endüstriyel kefir üretiminde kefir danesinden işletme kültürü oluşturulur. Süt homojenizasyon, ısıl işlem, soğutma ve mayalama gibi işlemlerden geçirilerek inkübasyona alınır. İnkübasyon sonunda pıhtının PH'sı 4.4-4.9, asitliği 30-40 SH olmaktadır. Pıhtı $12-14{ }^{\circ} \mathrm{C}^{\prime}$ de 24 saat olgunlaştırma işlemine alınır ve ardından paketleme işlemi yapılır (Üstün ve Gökçe, 2013).

Kefir, Eski Sovyetler Birliği'ndeki Kafkasya Dağlarında ortaya çıkmış ve binlerce yıldır tüketilmiştir. Eski Sovyetler Birliği, Macaristan ve Polonya'da çok ilgi görmüştür. Bu ülkelerin yanı sıra Norveç, Finlandiya, Almanya, İsveç, Yunanistan, Brezilya ve İsrail'de de bilinmektedir. Japonya ve Amerika Birleşik Devletleri'nde de git gide ilgi görmeye başlamıştır. Dünya'nın birçok yerinde mikroorganizmalardan üretilen kefir benzeri ürünler bulunmaktadır. Bu gruptaki ürünler; Doğu ve Batı Afrika'da Omoere, bazı Arap ülkelerinde Rob veya Roba, Norveç'te Kjaklder
Mjoklk, Almanya'da Kellermilch, Moğolistan'da Tarag ve Türkiye'de kefir isimleriyle bilinmektedir (Otles ve Çağındı, 2003).

Çalışmada kefir tüketimi Antalya kent merkezi örneğinde irdelenmiştir. Kefir tüketimi, tüketicilerin tercihi, alışkanlıkları konularında çalışmalar oldukça sınırlıdır. Bu çalışmalardan bazıları şunlardır; Kefir kullanılarak yapılan bazı süt ürünleri bulunmaktadır. Kefir yoğurdu, kefir dondurması, çeşitli kefir içecekleri, kefir tarhanası ve kefir peyniri hakkında çeşitli bilgiler elde edilmiş ve endüstriyel üretimleri yapılmıştır. Fakat kefir gibi bu ürünler hakkında da yeterli bilgi sahibi olunmadığı ve tüketiminin kısıtlı olduğu anlaşıımıştır (Esmek ve Güzeler, 2015). Türkiye'de yapılan başka bir çalışmada farklı düzeylerde kefir tanesi içeren simit örnekleri incelenmiştir. Bu çalışmada kefir tanelerinin hamuru mayaladığı görülmüş ve kefir taneleri kullanılarak simit üretiminin gerçekleştirilebileceği saptanmıştır (Şentürk ve Ötleş, 2017). Bu durum çalışmanın özgünlüğünü artırmaktadır. Ayrıca tüketimi üzerinde etkili faktörler Lojistik regresyon analizi yöntemiyle analiz edilmiştir. Çalışma kefir üretimi yapan tüm firmalar için önem arz etmektedir.

\section{MATERYAL ve YÖNTEM}

$\mathrm{Bu}$ çalışmanın ana materyalini, Antalya ili kent merkezinde tüketicilerinden anket yoluyla elde edilen veriler oluşturmuştur. Ayrıca konu ile ilgili yayınlardan da yararlanılmıştır. Veriler 2018 Kasım döneminde toplanmıştır.

Çeşitli araştırmalarda uygulamada farklı ana kitle büyüklükleri ve tolerans düzeyleri için belirli güven sınırları ve belirli ana kitle varyansı varsayılarak farklı örnek büyüklükleri kullanılmaktadır (Kurtuluş, 1998). Bu çalışmada örnek ilçelerin saptanması TÜiK verileri dikkate alınarak Kepez, Muratpaşa ve Konyaaltı ilçeleri hedef ana kitle olarak belirlenmiştir.

Hedef olarak belirlenen ana kitle basit tesadüfi örnekleme yöntemi uygulanarak görüşülecek tüketici sayısı \%95 güven, $\% 5$ hata payı ile 384 tüketici olarak belirlenmiştir. Buna göre, Kepez ilçesinde 172 tüketici, Muratpaşa'da 154 tüketici, Konyaaltı'nda 58 tüketici ile görüşülmüştür.

Anket soruları çalışmanın amacına uygun olarak kefir tüketimi ve tüketici davranış yapılarını içeren ayrıntılı sorulardan oluşmuştur. Tüketicilerin memnuniyet, tercih, yargı ifadelerini belirlemede 5 'li likert ölçeği kullanılmıştır.

Çalışmada kurulan hipotezlerin analizinde Ki-kare bağımsızlık testi kullanılmıştır. (1. Hipotez; H11: Kefir tüketimi ile cinsiyet arasında bir ilişki vardır-H10: Kefir 
tüketimi ile cinsiyet arasında bir ilişki yoktur. 2. Hipotez; H21: Kefir tüketimi ile eğitim arasında bir ilişki vardırH20: Kefir tüketimi ile eğitim arasında bir ilişki yoktur. 3 . Hipotez; H31: Kefir tüketimi ile yaş arasında bir ilişki vardır- H30: Kefir tüketimi ile yaş arasında bir ilişki yoktur). Ki-kare testleri, nicel ve nitel değişkenlerin özel, çapraz ve içiçe sınıflandırma biçimlerine göre gruplandırılması durumlarında kurulan varsayımların test edilmesi için yararlanılan testlerin ortak adıdır (Özdamar, 2018). Bu çalışmada ki-kare bağımsızlık testi kullanılmıştır. $\mathrm{Bu}$ test, $\mathrm{n}$ biriminden elde edilen iki değişkenin kategorilerine göre çapraz tablo biçiminde düzenlendiğinde, birimlerin değişken kategorilerine göre dağılımlarının bağımsız ya da bağımlı olma durumunu test etmede yararlanılan bir testtir (Özdamar, 2018).

Ayrıca kefir tüketimi üzerinde etkili faktörler Lojistik regresyon analizi yöntemiyle analiz edilmiştir. Lojistik regresyon analizi; bağımlı değişkenin kategorik olarak (ikili, üçlü ve çoklu kategorilerde) elde edildiği/kullanıldığı koşullarda, açıklayıcı değişkenlerle neden sonuç ilişkisini belirlemede faydalanılan bir yöntemdir (Özdamar, 2004). Logistik model, ortaya çıkacak riski 0 ile 1 arasında herhangi bir değer olarak

Çizelge 1. Tüketicilerin gelir- harcama durumları

Table 1. Consumers 'income-spending situations

\begin{tabular}{lccc}
\hline & Kefir Tüketmeyen & Kefir Tüketen & Toplam/Ortalama \\
\hline Aile ortalama aylık gelir & 4174.45 & 5608.93 & 4592.84 \\
Hane aylık toplam gıda harcaması & 902.21 & 1025.89 & 938.28 \\
Hane aylık toplam süt ve süt ürünleri harcaması & 278.51 & 307.28 & 286.90 \\
\hline
\end{tabular}

Görüşülen bireylerin bazı demografik özellikleri Çizelge 2 'de verilmiştir. Görüşme yapılan bireylerin içerisinde kefir tüketmeyenlerin ortalama yaşı 40.45, kefir tüketenlerin ortalama yaşı ise 34.79 , genel ortalama yaş ise $38.8^{\prime}$ dir. Kefir tüketmeyenlerin $\% 53.31^{\prime} \mathrm{i}$, kefir tüketenlerin $\% 51.79$ 'u kadın, kefir tüketmeyenlerin $\% 46.69$ 'u, kefir tüketenlerin \%48.21'i erkektir. Hane büyüklüğü kefir tüketmeyenlerde 2.58 iken kefir tüketenlerde 2.85 kişi ve genel ortalama 2.66 kişidir. Görüşülen bireyler içerisinde çalışan erkek sayısı kefir tüketmeyenlerde 0.64 iken kefir tüketenlerde 0.88 kişidir. Çalışan kadın sayısı kefir tüketmeyenlerde 0.32 iken kefir tüketenlerde 0.60 kişidir. Şehirde yaşama süresi kefir tüketmeyenlerde 29.92 yıl iken kefir tüketenlerde 29.97 yıldır. Görüşülen bireyler içerisinde tahmin etmeye yaramaktadır (Hosmer ve Lemeshow, 1980; Hosmer ve Lemeshow, 2000). Hanehalklarının kefir tüketimini ve satın alımlarını etkileyen sosyoekonomik ve demografik özelliklerin belirlenmesi amacıyla bu model kullanılmıştır. Tahmin edilecek modelde kefir tüketimi bağımlı değişken olarak tanımlanmıştır.

\section{BULGULAR ve TARTIŞMA}

\section{Tüketicilerin Demografik Özellikleri}

Görüşülen bireyler içerisinde kefir tüketmeyenlerin ortalama aylık geliri $4174.45 \mathrm{TL}$, kefir tüketenlerin ortalama aylık geliri 5608.93 TL olup genel ortalama aylık gelir 4592.84 TL'dir. Bunun yanında kefir tüketmeyenlerin ortalama aylık toplam gıda harcaması 902.21 TL, kefir tüketenlerin 1025.89 TL olup genel ortalama aylık toplam gıda harcaması 938.28 TL'dir. Kefir tüketmeyenlerin ortalama aylık süt ve süt ürünleri harcaması 278.51 TL iken kefir tüketenlerin ortalama aylık toplam süt ve süt ürünleri harcaması $307.28 \mathrm{TL}$ ve genel ortalama aylık toplam süt ve süt ürünleri harcaması 286.90 TL'dir (Çizelge 1). kefir tüketmeyenlerin \% 29.41'i, kefir tüketenlerin \%36.61'i bekâr, kefir tüketmeyenlerin \%67.65'i, kefir tüketenlerin \%61.61'i evli, kefir tüketmeyenlerin \%1.47'si, kefir tüketenlerin \%1.79'u boşanmış, kefir tüketmeyenlerin \%1.47'si eşini kaybetmiştir. Kefir tüketmeyenlerin $\% 51.47$ 'si, kefir tüketenlerin $\% 49.11$ 'i ev sahibi olup, kefir tüketmeyenlerin $\% 49.63$ ü, kefir tüketenlerin \%55,36'sı otomobil sahibidir. Kefir tüketmeyenlerin $\% 73,53^{\prime}$ ü, kefir tüketenlerin $\% 93.75^{\prime} i$ bilgisayar sahibi olup, kefir tüketmeyenlerin \%71.32'si, kefir tüketenlerin \%89.29'u internet sahibidir. Kefir tüketmeyenlerde internet sahiplik süresi 5.24 yıl iken, kefir tüketenlerde 7.22 yıldır. 
Çizelge 2. Tüketicilerin bazı demografik özellikleri

Table 2. Some demographics of consumers

\begin{tabular}{|c|c|c|c|}
\hline Özellikler & Kefir Tüketmeyen & Kefir Tüketen & Toplam/ Ortalama \\
\hline Görüşülen bireyin yaşı (yıl) & 40.45 & 34.79 & 38.8 \\
\hline Görüşülen kadın birey sayısı & 53.31 & 51.79 & 52.55 \\
\hline Görüşülen erkek birey sayısı ( \%) & 46.69 & 48.21 & 47.45 \\
\hline Hane büyüklüğü ( kişi) & 2.58 & 2.85 & 2.66 \\
\hline Şehirde yaşama süresi (yıl) & 29.92 & 29.97 & 29.94 \\
\hline Hanelerde çalışan erkek sayısı (kişi) & 0.64 & 0.88 & 0.71 \\
\hline Hanelerde çalışan kadın sayısı ( kişi ) & 0.32 & 0.60 & 0.40 \\
\hline \multicolumn{4}{|l|}{ Medeni Durum } \\
\hline Bekar (\%) & 29.41 & 36.61 & 33.01 \\
\hline Evli ( \%) & 67.65 & 61.61 & 64.63 \\
\hline Boşanmış ( \%) & 1.47 & 1.79 & 1.63 \\
\hline Eşini kaybetmiş ( \%) & 1.47 & 0.00 & 0.73 \\
\hline \multicolumn{4}{|l|}{ Hanelerde Nüfus Dağılımı } \\
\hline 0-3 erkek ( kişi) & 0.03 & 0.02 & 0.03 \\
\hline 0-3 kadın ( kişi) & 0.02 & 0.04 & 0.02 \\
\hline 4-6 erkek ( kişi) & 0.06 & 0.11 & 0.08 \\
\hline 4-6 kadın( kişi) & 0.04 & 0.11 & 0.06 \\
\hline 7-14 erkek ( kişi) & 0.10 & 0.10 & 0.10 \\
\hline 7-14 kadın ( kişi) & 0.11 & 0.12 & 0.11 \\
\hline 15-18 erkek ( kişi) & 0.04 & 0.04 & 0.04 \\
\hline 15-18 kadın ( kişi) & 0.05 & 0.05 & 0.05 \\
\hline 19-24 erkek ( kişi) & 0.18 & 0.15 & 0.17 \\
\hline 19-24 kadın ( kişi) & 0.13 & 0.17 & 0.14 \\
\hline 25-34 erkek ( kişi) & 0.19 & 0.33 & 0.23 \\
\hline 25-34 kadın ( kişi) & 0.26 & 0.36 & 0.29 \\
\hline 35-44 erkek ( kişi) & 0.19 & 0.26 & 0.21 \\
\hline 35-44 kadın ( kişi) & 0.22 & 0.19 & 0.21 \\
\hline 45-54 erkek ( kişi) & 0.16 & 0.16 & 0.16 \\
\hline 45-54 kadın ( kişi) & 0.15 & 0.27 & 0.19 \\
\hline 55-64 erkek ( kişi) & 0.19 & 0.23 & 0.21 \\
\hline 55-64 kadın ( kişi) & 0.25 & 0.13 & 0.21 \\
\hline 65-74 erkek ( kişi) & 0.14 & 0.01 & 0.10 \\
\hline 65-74 kadın ( kişi) & 0.04 & 0.03 & 0.04 \\
\hline 75+ erkek ( kişi) & 0.00 & 0.01 & 0.01 \\
\hline $75+$ kadın ( kişi) & 0.00 & 0.00 & 0.00 \\
\hline Ev sahibi (\%) & 51.47 & 49.11 & 50.29 \\
\hline Otomobil sahibi ( \%) & 49.63 & 55.36 & 52.49 \\
\hline Bilgisayar sahibi ( \%) & 73.53 & 93.75 & 83.64 \\
\hline İnternet sahibi ( \%) & 71.32 & 89.29 & 80.3 \\
\hline İnternet sahiplik süresi (yıl) & 5.24 & 7.22 & 5.82 \\
\hline
\end{tabular}

Yapılan ki-kare bağımsızlık testine göre kefir tüketimi ile cinsiyet arasında ilişki varlığının bulunmadığı saptanmıştır ( $P>0,05 ; P>0,786$; H10:Kefir tüketimi ile cinsiyet arasında bir ilişki yoktur.--H11:Kefir tüketimi ile cinsiyet arasında bir ilişki vardır.)

Kefir tüketimi ile eğitim arasında ise bir ilişki bulunmaktadır ( $P<0,05 ; H 20$ :Kefir tüketimi ile eğitim arasında bir ilişki vardır.--H21:Kefir tüketimi ile eğitim arasında bir ilişki vardır.). Deneklerin eğitim seviyesi üniversite düzeyi ve üzerine yükseldiğinde kefir tüketim oranları da artmaktadır.

Kefir tüketimi ile yaş değişkeni arasında da bir ilişki bulunmaktadır $(\mathrm{P}<0,05 ; \mathrm{H} 30$ :Kefir tüketimi ile yaş arasında bir ilişki yoktur.----H31:Kefir tüketimi ile yaş arasında bir ilişki vardır.). Deneklerin yaşının 40 ve altında olması kefir tüketim oranlarını artmaktadır. 
Görüşülen deneklerin eğitim durumu Çizelge 3'de verilmiştir. Çizelgeye göre kefir tüketmeyenlerin \%3.31'i ilkokul mezunu, \%26.47'si ortaokul mezunu, \%33.46'sı lise mezunu, \%34.56'sı üniversite mezunu, \%1.84'ü yüksek lisans / doktora mezunudur. Kefir tüketenlerin

Çizelge 3. Tüketicilerin eğitim durumu

Table 3. Consumers 'educational status

\begin{tabular}{lcccc}
\hline \multirow{2}{*}{ Eğitim düzeyi } & \multicolumn{2}{c}{ Kefir Tüketmeyen } & \multicolumn{2}{c}{ Kefir Tüketen } \\
\cline { 2 - 5 } & $\mathrm{N}$ & $\%$ & $\mathrm{~N}$ & $\%$ \\
\hline Okuryazar değil & 1 & 0.37 & 0 & 0.00 \\
Okuryazar & 0 & 0.00 & 1 & 0.89 \\
ilkokul mezunu & 9 & 3.31 & 1 & 0.89 \\
Ortaokul mezunu & 72 & 26.47 & 6 & 5.36 \\
Lise mezunu & 91 & 33.46 & 40 & 35.71 \\
Üniversite mezunu & 94 & 34.56 & 59 & 52.68 \\
Yüksek lisans/ Doktora & 5 & 1.84 & 5 & 4.46 \\
\hline
\end{tabular}

Tüketicilerin doğum yerleri Çizelge 4'te verilmiştir. Çizelgeye göre kefir tüketmeyenlerin \%37.13'ü ilçe, \%33.46'sı büyükşehir, \%17.65'i il merkezi, \%10.66'sı köy, \%1.10'u kasabada doğmuştur. Kefir tüketenlerin

\%54.46'sı büyükşehir, \%18.75'i ilçe, \%16.96'sı il merkezi, \%6.25'i köy, \%3.57'si kasabada doğmuştur.
$\% 5.36$ 'sı ortaokul mezunu, \%35.71'i lise mezunu, $\% 52.68$ 'i üniversite mezunu, \%4.46'sı yüksek lisans / doktora mezunudur.

Çizelge 4. Tüketicilerin doğum yeri

Table 4. Birthplace of consumers

\begin{tabular}{lcccccc}
\hline & & Büyükşehir & II merkezi & İlçe & \multicolumn{2}{c}{ Kasaba } \\
\cline { 2 - 7 } Kefir Tüketmeyen & $\mathrm{N}$ & 91 & 48 & 101 & 3 & 29 \\
& $\%$ & 33.46 & 17.65 & 37.13 & 1.10 & 10.66 \\
\cline { 2 - 7 } Kefir Tüketen & $\mathrm{N}$ & 61 & 19 & 21 & 4 & 7 \\
& $\%$ & 54.46 & 16.96 & 18.75 & 3.57 & 6.25 \\
\hline
\end{tabular}

\section{Tüketicilerin Kefir Tüketim Durumları ve Bilgileri}

Görüşülen bireylerin \%70.83'ü kefir tüketmemektedir. Antalya kent merkezinde tüketicilerin \%29.17'si kefir tüketmektedir (Çizelge 5).

Görüşülen bireyler içerisinde kefir tüketmeyenlerin \%33.82'si kefiri ile ve arkadaş çevresinden, \%34.93'ü TV

Çizelge 5. Tüketicilerin kefir tüketme durumu

Table 5. The state of consumers consuming kefir

\begin{tabular}{lcc}
\hline & $\mathrm{N}$ & $\%$ \\
\hline Kefir Tüketmeyen & 272 & 70.83 \\
Kefir Tüketen & 112 & 29.17 \\
Toplam & 384 & 100.00 \\
\hline
\end{tabular}

reklamlarından duyduğunu, $\% 30.51^{\prime} i$ ise duymadığını belirtmiştir. Kefir tüketenlerin ise \%69.64'ü kefiri aile ve arkadaş çevresinden, $\% 27.68^{\prime} i$ internetten, $\% 6.25^{\prime} \mathrm{i}$ ise TV reklamlarından duyduğunu belirtmiştir (Çizelge 6). 
Çizelge 6. Tüketicilerin kefir ile ilgili duyum kanalları

Table 6. Consumers 'sensation channels related to kefir

\begin{tabular}{|c|c|c|c|c|}
\hline Duyum kanalı & & Kefir Tüketmeyen & Kefir Tüketen & Toplam \\
\hline \multirow{2}{*}{ Aile ve arkadaş çevresi } & $\mathrm{N}$ & 92 & 78 & 170 \\
\hline & $\%$ & 33.82 & 69.64 & 44.27 \\
\hline \multirow{2}{*}{ TV reklam } & $\mathrm{N}$ & 95 & 7 & 102 \\
\hline & $\%$ & 34.93 & 6.25 & 26.56 \\
\hline \multirow{2}{*}{ İnternet } & $\mathrm{N}$ & 2 & 31 & 33 \\
\hline & $\%$ & 0.74 & 27.68 & 8.59 \\
\hline \multirow{2}{*}{ Basılı medya } & $\mathrm{N}$ & 2 & 1 & 3 \\
\hline & $\%$ & 0.74 & 0.89 & 0.78 \\
\hline \multirow{2}{*}{ Market } & $\mathrm{N}$ & 5 & 1 & 6 \\
\hline & $\%$ & 1.84 & 0.89 & 1.56 \\
\hline \multirow{2}{*}{ Ziraat fakültesi } & $\mathrm{N}$ & 0 & 1 & 1 \\
\hline & $\%$ & 0 & 0.89 & 0.26 \\
\hline \multirow{2}{*}{ Bilmiyor } & $\mathrm{N}$ & 83 & 0 & 83 \\
\hline & $\%$ & 30.51 & 0 & 21.61 \\
\hline Toplam & $\mathrm{N}$ & 272 & 112 & 384 \\
\hline
\end{tabular}

Görüşülen bireylerin \%41.96'sı kefir tüketmelerinde sağlık sorunlarının, \%57.14'ü tavsiyelerin, \%2.68'i ise sağlık faydalarının etkisi olduğunu belirtmiştir (Çizelge 7).Görüşülen bireylerin \%62.50'si kefiri haftada 1 kez, $\% 25.89^{\prime} \mathrm{u}$ günde $1 \mathrm{kez}, \% 5.36$ 'sı 15 günde $1 \mathrm{kez}$

Çizelge 7. Tüketicilerin kefir tüketme nedenleri

Table 7. Reasons why consumers consume kefir

\begin{tabular}{lcc}
\hline & $\mathrm{N}$ & $\%$ \\
\hline Tavsiyeler & 67 & 57.14 \\
Sağıık sorunları & 47 & 41.96 \\
Sağlığa faydası & 3 & 2.68 \\
Reklamlar & 2 & 1.79 \\
Araştırmalar & 1 & 0.89 \\
\hline
\end{tabular}

Çizelge 8. Tüketicilerin kefir tüketim sıklığı

Table 8. Consumers ' kefir consumption frequency

\begin{tabular}{lcc}
\hline & N & $\%$ \\
\hline Haftada 1 kez & 70 & 62.50 \\
Günde 1 kez & 29 & 25.89 \\
15 Günde 1 kez & 6 & 5.36 \\
Ayda 1 kez & 5 & 4.46 \\
Günde2-3 kez & 2 & 1.79 \\
\hline
\end{tabular}

Çizelge 9. Kefirin sağlık sorunlarına katkı sağlama durumu

Table 9. Contribution to health problems of kefir

\begin{tabular}{lcc}
\hline & $\mathrm{N}$ & $\%$ \\
\hline Dolaşım sistemi sorunları & 5 & 4.46 \\
Sindirim sistemi sorunları & 56 & 50.00 \\
Bağışıklı sisteminin güçlendirilmesi & 99 & 88.39 \\
Kansere olan etkisi & 1 & 0.89 \\
\hline
\end{tabular}


Görüşülen tüketiciler içerisinde kefir tüketmeyenlerin \%52.57'si kefirin yararları hakkında bilgisinin olmadığını belirtirken, \%47.43'ü kefirin yararları hakkında bilgisinin olduğunu belirtmiştir (Çizelge 10).

Çizelge 10. Tüketicilerin kefirin yararları hakkında bilgi durumu

Table 10. State of information about the benefits of kefir for consumers

\begin{tabular}{lccc}
\hline Bilgisi & & Kefir Tüketmeyen & Kefir Tüketen \\
\hline \multirow{2}{*}{ Evet var } & $\mathrm{N}$ & 129 & 112 \\
& $\%$ & 47.43 & 100.00 \\
\cline { 2 - 4 } Hayır yok & $\mathrm{N}$ & 143 & 0 \\
& $\%$ & 52.57 & 0.00 \\
\hline
\end{tabular}

Görüşülen bireylerin kefirin yararları hakkındaki görüşleri çizelge $11^{\prime}$ de verilmiştir. Buna göre, tüketicilerin kefirin bağışıklık sistemini güçlendirmesi hakkındaki görüşleri; \%36.20'si bu görüşe katıldığını, \%35.94'ü fikrinin olmadığını, \%26.82'si kesinlikle katıldığını belirtmiştir. Tüketicilerin kefirin kansere yol açan tümörlere karşı etkili olması hakkındaki görüşleri; \%89.58'i fikrinin olmadığını, \%5.47'si ise kararsız olduklarını belirtmiştir. Tüketicilerin kefirin alerji ve astım üzerine etkili olması hakkındaki görüşleri; \%82.03'ü fikrinin olmadığını belirtirken \%13.28'i kararsız olduğunu belirtmiştir. Tüketicilerin kefirin kemiklere ve kemik gelişimine iyi gelmesi hakkındaki görüşleri; \%42.97'si fikrinin olmadığını, \%38.80'i katıldığını, \%15.10'u kesinlikle katıldığını belirtmiştir. Tüketicilerin kefirin kötü kolesterolü düşürmesi hakkındaki görüşleri ; \%87.24'ü fikrinin olmadığını belirtirken, \%8.59'u kararsız olduğunu belirtmiştir. Tüketicilerin kefirin gastrit tedavisinde etkili olması hakkındaki görüşleri; \%71.35'i fikrinin olmadığını belirtirken, \%22.14'ü kararsız olduğunu, \%4.95'i bu görüşe katıldığını belirtmiştir. Tüketicilerin kefirin rahatsız bağırsak sendromuna iyi gelmesi hakkındaki görüşleri; \%44.27'si fikrinin olmadığını belirtirken, \%27.08'i katıldığını, \%25.78'i kesinlikle katıldığını belirtmiştir. Tüketicilerin kefirin yüksek tansiyonu düşürmesi hakkındaki görüşleri; \%89.84'ü fikrinin olmadığını belirtirken, \%7.55'i kararsız olduğunu belirtmiştir. Tüketicilerin kefirin sindirim metabolizmasını çalıştırması hakkındaki görüşleri; \%35.94'ü fikrinin olmadığını belirtirken, \%32.81'i katıldığını, \%30.47'si kesinlikle katıldığını belirtmiştir.

Çizelge 11. Tüketicilerin kefirin yararları hakkındaki görüşleri

Table 11. Consumers 'views on the benefits of kefir

\begin{tabular}{|c|c|c|c|c|c|c|c|}
\hline & & $\begin{array}{l}\text { Fikrim } \\
\text { yok }\end{array}$ & $\begin{array}{c}\text { Kesinlikle } \\
\text { katılmıyorum }\end{array}$ & Katılmıyorum & Kararsızım & Katılıyorum & $\begin{array}{c}\text { Kesinlikle } \\
\text { katılıyorum }\end{array}$ \\
\hline \multirow{2}{*}{ Sindirim metabolizmasını çalıştırır } & $\mathrm{N}$ & 138 & 0 & 0 & 3 & 126 & 117 \\
\hline & $\%$ & 35.94 & 0 & 0 & 0.78 & 32.81 & 30.47 \\
\hline \multirow{2}{*}{ Bağışıklık sistemini güçlendirir } & $\mathrm{N}$ & 138 & 1 & 0 & 3 & 139 & 103 \\
\hline & $\%$ & 35.94 & 0.26 & 0 & 0.78 & 36.2 & 26.82 \\
\hline \multirow{2}{*}{$\begin{array}{l}\text { Rahatsız bağırsak sendromuna iyi } \\
\text { gelir }\end{array}$} & $\mathrm{N}$ & 170 & 0 & 0 & 11 & 104 & 99 \\
\hline & $\%$ & 44.27 & 0 & 0 & 2.86 & 27.08 & 25.78 \\
\hline \multirow{2}{*}{ Gastrit tedavisinde etkilidir } & $\mathrm{N}$ & 274 & 1 & 1 & 85 & 19 & 4 \\
\hline & $\%$ & 71.35 & 0.26 & 0.26 & 22.14 & 4.95 & 1.04 \\
\hline \multirow{2}{*}{$\begin{array}{l}\text { Kansere yol açan tümörlere karşı } \\
\text { etkilidir }\end{array}$} & $\mathrm{N}$ & 344 & 1 & 4 & 21 & 11 & 3 \\
\hline & $\%$ & 89.58 & 0.26 & 1.04 & 5.47 & 2.86 & 0.78 \\
\hline \multirow{2}{*}{ Alerji ve astım üzerine etkilidir } & $\mathrm{N}$ & 315 & 1 & 8 & 51 & 6 & 3 \\
\hline & $\%$ & 82.03 & 0.26 & 2.08 & 13.28 & 1.56 & 0.78 \\
\hline \multirow{2}{*}{ Kötü kolesterolü düşürür } & $\mathrm{N}$ & 335 & 0 & 5 & 33 & 8 & 3 \\
\hline & $\%$ & 87.24 & 0 & 1.3 & 8.59 & 2.08 & 0.78 \\
\hline \multirow{2}{*}{ Yüksek tansiyonu düşürür } & $\mathrm{N}$ & 345 & 1 & 2 & 29 & 4 & 3 \\
\hline & $\%$ & 89.84 & 0.26 & 0.52 & 7.55 & 1.04 & 0.78 \\
\hline \multirow{2}{*}{$\begin{array}{l}\text { Kemiklere ve kemik gelişimine iyi } \\
\text { gelir }\end{array}$} & $\mathrm{N}$ & 165 & 0 & 1 & 11 & 149 & 58 \\
\hline & $\%$ & 42.97 & 0 & 0.26 & 2.86 & 38.8 & 15.1 \\
\hline
\end{tabular}

Kefir tüketmeyenlerin \%45.96'sı hakkında bilgisi olmadığı için, \%37.87'si ihtiyaç duymadığı için, \%29.41'i lezzetsiz bulduğu için kefir tüketmediğini belirtmiştir (Çizelge 12). 
Çizelge 12. Tüketicilerin kefir tüketmeme nedenleri Table 12. Reasons why consumers do not consume kefir

\begin{tabular}{lcc} 
Kefir tüketmeme nedenleri & $\mathrm{N}$ & $\%$ \\
\hline Hakkında bilgim yok & 125 & 45.96 \\
İhtiyaç duymuyorum & 103 & 37.87 \\
Lezzetsiz buluyorum & 80 & 29.41 \\
Pahalı buluyorum & 4 & 1.47 \\
\hline
\end{tabular}

Kefir tüketmeyenlerin \%82.72'si sağlık sorunlarının olması durumunda kefiri tüketebileceklerini belirtirken, $\% 27.21^{\prime} \mathrm{i}$ tadı iyileştirilirse, \%1.47'si ise fiyatının düşürülmesi durumunda kefir tüketebileceklerini belirtmiştir (Çizelge 13).

Çizelge 13. Kefiri hangi durumda tüketirsiniz Table 13. In which case do you consume kefir

\begin{tabular}{lcc}
\hline Tüketme koşulları & $\mathrm{N}$ & $\%$ \\
\hline Sağıık sorunlarım olursa & 225 & 82.72 \\
Tadı iyileştirilirse & 74 & 27.21 \\
Fiyatı düşürülürse & 4 & 1.47 \\
\hline
\end{tabular}

Kefir tüketenlerin \%84.82'si kefiri sade, \%29.46'sı kefiri orman meyveli, \%3.57'si ise kefiri çilekli tükettiklerini belirtmiştir (Çizelge 14). Bölgede kefir genellikle sade olarak tüketilmektedir.

Çizelge 14. Tüketicilerin kefir çeşit tercihleri

Table 14. Consumers ' kefir variety preferences

\begin{tabular}{lcc}
\hline & $\mathrm{N}$ & $\%$ \\
\hline Sade & 95 & 84.82 \\
Orman meyveli & 33 & 29.46 \\
Çilekli & 4 & 3.57 \\
Muzlu & 1 & 0.89 \\
\hline
\end{tabular}

Kefir tüketenlerin \%59.82'si Altınkılıç Kefir markasını tercih ederken, \%41.07'si Eker Kefir markasını, \%13.39'u kefiri evde yaptıklarını, \%8.93'ü Ülker-içim Kefir markasını, \%8.93'ü Atatürk Orman Çiftliği markasını tercih ettiklerini belirtmiştir (Çizelge 15).
Çizelge 15. Tüketicilerin kefir marka tercihleri Table 15. Consumers ' kefir brand preferences

\begin{tabular}{lcc}
\hline & $\mathrm{N}$ & $\%$ \\
\hline Altınkılıç Kefir & 67 & 59.82 \\
Eker Kefir & 46 & 41.07 \\
Ülker - İçim Kefir & 10 & 8.93 \\
Atatürk Orman Çiftliği & 10 & 8.93 \\
Danone Kefir & 4 & 3.57 \\
Dane Kefir & 2 & 1.79 \\
Evde Kefir Yapımı & 15 & 13.39 \\
\hline
\end{tabular}

Kefir tüketenlerin \%66.96'sı tercih ettikleri markayı kaliteli olduğu için, \%45.54'ü güvenilir marka olduğu için, \%4.46'sı fiyatının ucuz olduğu için tercih ettiklerini belirtmiştir ( Çizelge 16).

Çizelge 16. Tüketicilerin tercih edilen markayı satın alma nedenleri

Table 16. Reasons consumers buy the preferred brand

\begin{tabular}{lcc}
\hline & $\mathrm{N}$ & $\%$ \\
\hline Kaliteli olması & 75 & 66.96 \\
Güvenilir marka olması & 51 & 45.54 \\
Fiyatının ucuz olması & 5 & 4.46 \\
Doğal olması & 2 & 1.79 \\
ilk marka olması & 1 & 0.89 \\
\hline
\end{tabular}

Görüşülen kefir tüketimi olan hanelerin aylık kefir tüketim miktarı 3125.90 ml'dir. Antalya ili kent merkezi ortalamasında ise hanelerde ortalama $911.72 \mathrm{ml}$ kefir tüketimi gerçekleşmektedir.

\section{Kefir Tüketimine Etki Eden Faktörlerin Analizi}

$\mathrm{Bu}$ bölümde kefir tüketim kararında etkili olan faktörlerin belirlenmesi amacıyla yapılan lojistik regresyon modeline ait sonuçlara yer verilmiştir. İkili (binary) lojistik regresyon modelinde kullanılan bağımsız değişkenler ve değişkenlere ilişkin tanımlamalar Çizelge 17 'de verilmiştir.

Çizelge 17. ikili (binary) lojistik regresyon modelinde kullanılan bağımsız değişkenler ve değişkenlere ilişkin açıklamalar

Table 17. Description of arguments and variables used in binary logistic regression model

\begin{tabular}{ll}
\hline Değişken & \multicolumn{1}{c}{ Tanım } \\
\hline Yaş & Anket yapılan bireyin yaşı (0: 18-49 yaş; 1: 50 ve üzeri yaş) \\
Cinsiyet & Anket yapılan bireyin cinsiyeti (0: erkek; 1: kadın) \\
Eğitim & Anket yapılan bireyin eğitim seviyesi (0: okuryazar, ilkokul, ortaokul; 1: Lise ve üzeri \\
& eğitim seviyesi) \\
Doğum yeri & Anket yapılan bireyin doğum yeri (0: köy, kasaba; $1:$ illçe, il merkezi, büyükşehir) \\
Hane halkı ortalama geliri & Anket yapılan bireyin hane halkı geliri (0: 1000-4900 TL; 1: 5000 ve yukarı TL) \\
\hline
\end{tabular}


Bu modelde bağımlı değişken tüketicilerin kefir tüketme durumları (1: Tüketen; 0: Tüketmeyen) olarak belirlenmiştir. $\mathrm{Bu}$ modelin kurulmasındaki amaç tüketicilerin kefir tüketim durumunda etkili olan değişkenlerin belirlenmesidir. Modelde her bağımsız değişken için tahmin edilen katsayı, değişkenlerin standart hataları, odss oranları, anlamlılık düzeyleri ( $p$ değerleri) Çizelge $18^{\prime}$ de verilmiştir. Modelin Nagelkerke R2 değeri 0,130 olarak hesaplanmış olup bu değerin katsayısına göre modelde bulunan değişkenler modelin \%13'ünü açıklamaktadır. Yapılan analiz sonuçlarına göre -2 Log olasılık değeri 426,809 ve olasılıkların doğru tahmin oranı ise $\% 71.9$ olarak hesaplanmıştır.

Elde edilen sınıflandırma tablosuna göre model tüm olasılıkların \%71.9'unu doğru sınıflamıştır. Lojistik regresyon analiz sonuçlarına göre \%1 önemlilik düzeyi ele alındığında; bağımsız değişkenlerden en önemlisinin $(p=0,000)$ eğitim olduğu belirlenmiştir. Eğitim düzeyinin artması ile kefir tüketimi arasında ters bir ilişki olduğu, eğitim düzeyi artması kefir tüketim olasılığını düşürmektedir. Bununla birlikte kefir tüketimine negatif yönlü etki eden diğer bir faktör ise hane halkı ortalama gelir değişkeni olarak belirlenmiştir.

Doğum yeri değişkeni incelendiğinde; Büyükşehir, il merkezi ve ilçe doğumlu tüketicilerin, köy ve kasaba doğumlu tüketicilere göre kefir tüketme olasılığı 2,5 kat daha fazladır.

Çizelge 18. Binary Lojistik Regresyon Sonuçları

Table 18. Binary Logistic Regression Results

\begin{tabular}{lcccc}
\hline Değişkenler & Katsayı $(\beta)$ & Standart hata (SE) & P- değeri (Sig) & Odds Oranı Exp ( $\beta$ ) \\
\hline Yaş & -0.071 & 0.404 & 0.860 & 0.931 \\
Cinsiyet & -0.172 & 0.239 & 0.470 & 0.842 \\
Eğitim & -1.928 & 0.532 & $0.000^{* * *}$ & 0.145 \\
Doğum yeri & 0.936 & 0.497 & $0.060^{*}$ & 2.550 \\
Hane halkı ortalama geliri & -0.606 & 0.244 & $0.013^{* *}$ & 0.545 \\
Sabit & -0.207 & 0.440 & 0.638 & 0.813 \\
\hline
\end{tabular}

Nagelkerke $\mathrm{R}^{2}=0.130 ;-2$ Log Likelihood= 426.809; Percentage Correct $=\% 71.9$

$*, * *, * * *: \% 10, \% 5$ ve $\% 1$ anlamlılık düzeylerinde istatistiksel olarak anlamlıdır.

Araştırma bulgularına göre tüketicilerin \%70.83'ü kefir tüketmemektedir. Kefir tüketenlerin önemli kısmı kefiri aile ve arkadaş çevresinden duyduklarını belirtmiştir. Kefir tüketmeyenlerin $\% 30.51^{\prime} i$ ise kefiri hiç duymadıklarını ifade etmiştir. Kefir tüketmeyen bireylerin \%52.57'sinin kefirin yararları hakkında bilgi sahibi olmadığı saptanmıştır.

Araştırma bölgesinde kefir tüketmeyen tüketicilerin bilinçlendirilmesi önemlidir. Bölgede tüketicilerin büyük bir kısmının kefir ve kefirin insan sağlığı üzerine etkileri hakkında bilgi sahibi olmadıkları gözlemlenmiştir. Bunun için yapılan televizyon reklamlarının çok etkili olamadığı, farklı bilgilendirmeler ile bireylerin kefir hakkında bilgi sahibi olmaları sağlanmalıdır.

Bireylerin bilinçlendirilmesi, okullarda sağlık derslerine önem verilmesi ve çocuklara kefirin yararlarının anlatılması, tadım yapmaları için okullarda kefir dağıtılmasıyla ileride daha bilinçli bireyler yetişmesi sağlanabilir. Diğer yandan yetişkinler için belediyeler aracılığıyla açılan sağlık kurslarında kefir ve kefirin yararları hakkında bilgilendirmeler yapılabilir.

Ayrıca hali hazırda çeşitli meyvelerle aromalandırılmış olan kefir çeşitlerinin de tadı lezzetsiz bulunmaktadır. Kefir üreten firmalar kefirin tadını bireylerin sevecekleri şekilde değiştirebilirlerse kefir tüketiminde de artışlar sağlanabilir.

\section{ÖZET}

Amaç: Bu çalışmada, Antalya ili Merkez ilçelerindeki tüketicilerin kefir tüketim düzeylerinin belirlenmesi amaçlanmıştır. Ayrıca çalışma ile tüketicilerin kefir tüketimi üzerinde etkili olabilecek faktörler Lojistik regresyon analizi ile belirlenmiştir.

Yöntem ve Bulgular: Bu araştırmada; Antalya ili Merkez ilçeleri araştırma alanı olarak seçilmiştir. Araştırmanın ana materyalini 384 tüketiciden anket yoluyla toplanan veriler oluşturmaktadır. Tüketiciler 2 gruba (kefir tüketen ve tüketmeyen) ayrılarak incelenmiştir. Çalışma verileri Kasım 2018 dönemine aittir. Öncelikle hanelerin sosyo-ekonomik göstergeleri irdelenmiştir. Tüketicilerin kefir tüketim durumu, tüketim nedenleri, tüketici davranışları, kefir tüketimi konusunda tüketici bilinçlendirilmesi için öneriler ortaya konulmuştur. Lojistik regresyon analizi ile deneklerde kefir tüketimi üzerinde etkili faktörler araştırılmıştır. Kefir tüketimi ile cinsiyet, kefir tüketimi ile eğitim ve kefir tüketimi ile yaş arasında ilişki varlığı Ki-kare bağımsızlık testi kullanılarak test edilmiştir. 
Genel Yorum: Hanede kefir tüketim oranı \%29.17'dir. Logistik regresyon analizi sonuçlarında eğitim, hanehalkı ortalama geliri ve doğum yeri göstergeleri ile kefir tüketimi olasılığı istatistiki olarak ilişkilidir. Bu göstergeler istatistiki olarak da anlamlıdır.

Çalışmanın Önemi ve Etkisi: Kefir tüketimi, tüketicilerin tercihi, alışkanlıkları konularında çalışmalar oldukça sınırlıdır. Bu durum çalışmanın özgünlüğünü artırmaktadır. Ayrıca tüketimi üzerinde etkili faktörler Lojistik regresyon analizi yöntemiyle analiz edilmiştir. Çalışma kefir üretimi yapan tüm firmalar için önem arz etmektedir.

Anahtar Kelimeler: Kefir, tüketim, Logistik, tüketici, probiyotik, Antalya

\section{TEŞEKKÜR}

Bu çalışma 2209/A numaralı proje ile TÜBiTAK tarafından desteklenmiştir. Çalışmanın gerçekleştirilmesinde maddi destek sağlayan TÜBiTAK'a teşekkür ederiz.

\section{ÇIKAR ÇATIŞMA BEYANI}

Yazar(lar) çalışma konusunda çıkar çatışmasının olmadığını beyan eder.

\section{ARAŞTIRMACILARIN KATKI ORANI BEYANI}

Yazarlar çalışmaya eşit oranda katkı sağlamış olduklarını beyan eder.

\section{KAYNAKLAR}

Anonim (2009) Türk Gıda Kodeksi Fermente Süt Ürünleri Tebliği. Tarım ve Köy İşleri Bakanlığı, Tebliğ No: 2009/25.

Esmek EM , Güzeler N (2015) Kefir ve Kefir kullanılarak Yapılan Bazı Ürünler. Harran Tarım ve Gıda Bilimleri Dergisi, 19(4), 250-258.

Farnworth ER (2006) Kefir-a complex probiotic. Food Science and Technology Bulletin: Fu, 2(1), 1-17

Hosmer DW, Lemeshow S (1980) Goodness of fit tests for the multiple logistic regression model, Communications in Stat., A (9), 1043-1069.

Hosmer DW, Lemeshow S (2000) Applied Logistic Regression 2nd Ed. John Wiley and Sons, New York.

Karatepe P, Yalçın H (2014) Kefirli Sağlık. Iğdır Üniversitesi Fen Bilimleri Enstitüsü Dergisi, 4(2), 2330.

Kurtuluş K (1998) Pazarlama Araştırmaları. Avcıol Basım Yayın, Genişletilmiş Altıncı Baskı, İstanbul.
Oraman Y, Yılmaz E (2006) Tüketicilerin Süt Ürünleri Tüketim Yapıları ve Probiyotik Ürün Tercihlerini Etkilen Faktörlerin Değerlendirilmesi: Tekirdağ illi Örneği, Türkiye VII Tarım Ekonomisi Kongresi, Antalya, 1031-1037.

Otles S, Cagindi O (2003) Kefir: A probiotic dairycomposition, nutritional and therapeutic aspects. Pakistan journal of nutrition, 2(2), 54-59.

Özdamar K (2004) Paket Programlar ile İstatistiksel Veri Analizi. Genişletilmiş 5. Baskı, Kaan Kitabevi, Eskişehir.

Özdamar K (2018) Temel İstatistik Eğitim Sağlık ve Sosyal Bilimler İçin SPSS Uygulamalı Temel İstatistik. Nisan Kitabevi, 224s, Eskişehir.

Şentürk A, Ötleş S (2017) Farklı Düzeylerde Kefir Kullanımının simidin Bazı Fiziksel, Kimyasal ve Duyusal Özellikleri Üzerine Etkisi. Harran Tarım ve Gıda Bilimleri Dergisi, 21(4), 431-433.

Tomar O, Çağlar A, Akarca, G (2017) Kefir ve Sağlık Açısından Önemi. Afyon Kocatepe Üniversitesi Fen Ve Mühendislik Bilimleri Dergisi, 17(2), 834-853.

Üstün Ö, Gökçe R (2013) Yurtdışında Üretilen Fermente Süt İçecekleri. Gıda Mühendisleri Dergisi, 10, 24-29. 